\title{
Training and development of personnel in Russian companies
}

\author{
T.A.Soltitskaya, Ph.D. \\ Associate professor, HRM department, \\ School of management, St.Petersburg State University, \\ soltitskaya@som.pu.ru \\ T.E.Andreeva, Ph.D., \\ Junior lecturer, HRM department, \\ School of management, St.Petersburg State University, \\ tatiana_andreeva@mail.ru
}

This is a preprint of an article whose final and definitive form has been published in the Human Resources Management in Russia. Eds.:M.E.Domsch, T.Lidokhover. Ashgate Publishing Group, Contemporary Employment Relations series, Hampshire, UK, 2007

\section{To cite this article:}

Soltitskaya T., Andreeva T. (2007) "Training and development of personnel in Russian companies", Human Resources Management in Russia. Eds.:M.E.Domsch, T.Lidokhover. Ashgate Publishing Group, Contemporary Employment Relations series, Hampshire, UK, Pp.193-208.

Annotation. The article analyses human resources training and development practices in Russia. It discusses some most topical questions and problems that Russian companies face in this field. Training needs and approaches of contemporary Russian companies are structured and analyzed from several perspectives - in relation to types of information culture dominant in the company, to company's life cycle stage (in L.Greiner model) and to dominant ideas about role of of training and development in company strategy. The article is based on vast experience of authors in training and HRM consulting for Russian companies.

\section{Raising a problem}

Competition for quality and new standards of doing business in a global world call for creation of knowledge centers, efficient information policy and continuous training and development of personnel in contemporary companies. According to J.Kay's model of foundations of corporate success (8), one of three strategic sources of competitive advantages is organizational architecture that provides for efficient usage of corporate knowledge. Thus every company striving for expand beyond the limits of local business meets a challenge of building training and development system.

Let us start from specifying definitions. The term "training" has double meaning knowledge acquisition and skills development. Knowledge is an ability to answer questions about reasons, characteristics, mechanisms, dynamics of a phenomenon, process, event. Skills are capabilities to apply knowledge into practice. Organizational life, surely, requires both knowledge and skills.

The problem of efficient usage and development of organizational knowledge is undoubtedly an issue of the day for contemporary Russian companies. They face severe struggle with international competitors on many domestic markets, losing traditional price advantage as resources' costs gradually even out. Organizational skills and knowledge, management system, and other internal factors turn into key sources of competitiveness in such a situation, with 
training and development system among them. In this article we tried to analyze vast experience of St. Petersburg University School of Management in organization of corporate training programs.

Before starting discussion of various trends in corporate training, we would like to mark out several factors that, in our opinion, influence formation of training and development policies in Russian companies.

1) stage of life-cycle. Due specifics of domestic market economy development, most of Russian companies find themselves on one of the first three life-cycle stages in L.Greiner model (7). A position on life-cycle curve defines company's attitude to its internal resources in general, and training policy, most popular training topics, etc., in particular, to a great extent. Further we will discuss this influence in detail.

2) peculiarities of education system. Classical Russian system of education is mainly oriented on general professional development of an individual that influences Russian managers' view on training tasks and results.

Another factor, often mentioned in mass media, is frequent discrepancy between basic education and factual field of activities, both among managers and rank personnel. For the elder generations it can be explained with state policy for preferential development of technical education that existed few decades ago. When development of market economy led to formation of realistic demand for various professions, thousands of highly qualified engineers found themselves unclaimed on labor market as a result of this policy and started to look for employment in totally different fields. Interestingly, the variance between education and field of work occurs often among youth as well. It happens because higher education is often seen mostly as a way to develop intellectual facilities, therefore, formal profession is chosen by interest and/or accessibility of education, while factual work is chosen by market demand or by chance. In total all this leads to intensive need for functional training in many Russian companies.

C.Fey, A.Pavlovskaya and N.Tang (5) identified this factor in their comparative research of training systems in Russian, Chinese and Finnish companies. They found out that functional training is more relevant and needed for Russian and Chinese than for Finnish employees. It is explained by the fact that the first ones often do not have professional education and work in the field different from stated in their higher education diploma.

3) peculiarities of national business culture. Russian business culture is widely discussed in literature, but within the frames of this article we would like to draw attention to one particular trend. Rigid system of information secrecy developed in many Russian companies, first influenced by decades of functioning in "closed" bureaucratic system and later as a result of the lack of knowledge on principles of efficient management. Such companies restrict and strictly regulate information exchange between departments, and, even to greater extent, between different management levels. The guiding principle of such systems sounds like "employees need not know anything except their direct duties" (that are already quite narrowly defined).

We will discuss influence of this factor further in this text but let us make here an important remark. From the point of the view of many western specialists, such as P.Senge (12) and C.Argyris (6), knowledge possessed by organization is much bigger than just a sum of the knowledge of its employees. Individual training is an important but insufficient condition for formation of organizational intelligence and development of internal competitive advantages. D.Kim (9) believes that organizational learning starts only at the moment when employees share their knowledge and/or skills.

Let us analyze training and development practices in Russian companies from the standpoint of contemporary theoretical concepts..

\section{Stage of life-cycle and approach to personnel training and development.}

In our opinion the features of training and development policies in Russian companies can be correlated with key ideas of Larry Greiner life-cycle concept (7). As one may recall, 
Greiner's concept supposes that a company passes through particular stages in a process of its growth and development. These stages are growth through 1) creativity, 2) direction, 3) delegation, 4) coordination 5) collaboration. Key management tasks and problems, as well as key success factors are predetermined for each life cycle stage as they are influenced by company's development path.

Key training needs. Our experience shows that companies being on the first stage of their life-cycle - growth through creativity usually do not have clear training and development policy. Training programs in these companies often follow "fashion" trends and are mostly oriented on development of personnel loyalty and team spirit. Outcomes of such training programs are rarely followed up and assessed. Key factors of company development on this stage explain this trend.

In rare cases companies on this stage train their employees so that they develop some functional skills but then they concentrate on the skills that are crucial for company's survival (for example, knowledge of taxation regulations). Turning to ways to provide training, these companies use external training companies.

More active training takes place on this stage only if a business is connected with fast developing and high tech services. In this case raising the level of employees' skills (mostly that of technicians and engineers) becomes the main physiological need of a company. An organization that deals with constantly renewed equipment, changing services, etc. can not function successfully until this need is satisfied.

Individual and organizational training are two different things, as we mentioned earlier. However, on the first stage of the life-cycle of an organization this two types of training are equivalent because employees tend to exchange knowledge and skills when socializing informally.

Here are some examples of typical demands for training from companies on this stage. Several years ago sales training was "fashionable" and many famous companies ordered this training, though sales growth on this stage of development is usually caused by other factors. The new product - extreme training - has recently appeared on the market and it is becoming more and more popular among companies because they regard it mostly as corporate entertainment that increases loyalty.

In companies that are on the stage of growth trough direction priorities in training become more structured. As a company grows, maintaining order becomes more important and management takes steps to organize training. It introduces regulations and formal description of work tasks, makes written correspondence and reports necessary, etc. These are the first measures to maintain the same level of skills and knowledge in an organization, i.e. to separate organizational and individual knowledge and training. It is on this stage that elementary system of personnel internal training is being formed. As for the prior subjects of training, on this stage companies mostly focus on functional training in fields where they lack competence for the further development. For this group sales training is very popular.

On the next stage - growth through delegation - companies tend to show active interest in various types of training. Among the most popular topics we can mention the following ones:

$\square$ management training for middle management (the most typical demand for the last 2 years: "teach a manager to be a manager and to manage personnel")

building organizational structure

forming/strengthening corporate culture.

Companies of this group start to use training as a diagnostic instrument to estimate and develop personnel and they gradually develop corporate training centers. In their further development training centers that function successfully start to offer their services to other companies, sharing experience with their clients, for example. A lot of Russian distributor companies have such experience as they train both their employees and dealer partners during technical and management trainings, conferences, schools, dealer schools.

As for the programs for top-managers, in the last 2 years in capitals and big cities interest in training in strategic management arose (and this is apparently connected with a certain stage 
of growth). At the same time significant changes in demands and expectations from such training happen. Before it was mostly viewed as strategy development session, in essence - a brain storm session, with a trainer's main aim being to facilitate the process. Often neuro-linguistic specialists were involved. Recently demands have changed from such training to more academic education and within its limits top-managers are introduced with theoretical problems of strategic management and the experience of successful companies in strategy development.

We would also like to mention the situation with knowledge management in Russian companies. Nowadays this topic is being often discussed in the counties with developed economies. In our opinion and according to the Greiner model this problem becomes of current importance for companies which are on the fifth stage of growth, with the most part of Russian companies not having yet reached it. Coordination and collaboration as the important problem appear only in companies that work in the intellectual fields or in huge holdings. And for the most part of Russian companies, in our opinion, solving this problem is important only on the level of organizing circulation of information within a company.

Assessing results of training. According to the Greiner classification, as we think, the problem of more effective and clear assessment of training results most often arises in companies that are between the second and the third stages of development. To our mind, among such companies we can find two main groups of companies: those who have result-oriented culture and those whose culture is mainly oriented towards personnel motivation. Let us view their peculiarities.

Companies with result-orientated culture expect to get immediate results of training and want from training programs more than they can give. They want these programs to solve two problems: "to gain more money" or "to save time". That is why such companies are often disappointed with training results. Even if expected changes take place after training in a company, they develop usually more slowly than a manager wants and often he or she simply does not notice them. In such case satisfaction from training results can be increased, to our mind, in several ways:

to use only that type of training that gives immediate and guaranteed result (of course the range of such training services is not very wide),

- to introduce inner training manager in such companies so that he or she

could carry out combined assessment of training results. This is difficult to do for a usual personnel manager or external trainer,

$\square$ to explain a client the difference between knowledge and skills (and the speed of their development) and to introduce strict system of knowledge control at the end of training (tests, etc.).

As for companies whose culture is oriented towards personnel motivation, for them the main training result is that employees want to go on working in this company and to improve their working skills. In these companies detailed analyses of training needs is carried out before ordering a training program. Another peculiarity of this companies is that they are ready to realize long-lasting training programs as they see connection between employees' development and successful development of the company on the whole.

It is also interesting to see what Russian managers expect from strategy training (and how therefore they estimate training results), which, as we mentioned earlier, becomes more and more popular. Usually companies want to learn about modern strategy terminology and to develop common language for top-management team during the training so that it could facilitate strategy discussions and posing problems. For some companies this is the main expected result of strategy training. Others above terminology want either:

to agree about development strategy for the nearest future (i.e. to add practical training - brain storm - to theoretical training) - and in this case a trainer needs good facilitating skills plus to knowledge of strategy theories

or to get concrete "hints" from a trainer about how to develop a company further and in this case they want a trainer to be an industry expert or an authoritative consultant. 
We would like to note that here we mostly meant companies based on Russian capital. Foreign companies in Russia usually order functional training as they are mostly interested in acquiring specialized knowledge.

\section{Influence of organizational culture on personnel training policy.}

Let us analyze another aspect of training policy in Russian companies, the aspect of organizational culture. Organizational culture in many ways determines company's orientation towards personnel training and also peculiarities of training policy. E. Schein defines organizational culture as "accumulating training results on the base of previous success" (10).

Schein thinks that nowadays only few companies have training culture. Describing culture of a training-oriented organization, the researcher formulated characteristics of organizational culture that contributes to the development of training processes in a company and of culture that hinders development of employees' training motivation (table 1).

\begin{tabular}{|c|c|}
\hline Culture contributing to training & Culture hindering training \\
\hline $\begin{array}{l}\text { 1. Brings interests of all the sides in balance } \\
\text { (neither of the groups - consumers, hired } \\
\text { managers, providers, stockholders, local } \\
\text { authorities, etc. - is for managers the most } \\
\text { important because managers understand: each } \\
\text { of these groups, if it were allowed to dominate, } \\
\text { can delay the development of the company and } \\
\text { destroy it) }\end{array}$ & $\begin{array}{l}\text { 1. Distinguishes between "strict" and "soft" } \\
\text { problems (problems connected with fulfilling } \\
\text { tasks has priority over problems connected } \\
\text { with relationships among people) }\end{array}$ \\
\hline $\begin{array}{l}\text { 2. Is focused on people and not on systems } \\
\text { (managers think that people can learn and will } \\
\text { learn, that they appreciate training and } \\
\text { changes) }\end{array}$ & $\begin{array}{l}\text { 2. Is focused on systems and not on people } \\
\text { (rational technocratic approach to organizing, } \\
\text { with managers being busy creating and } \\
\text { maintaining systems) }\end{array}$ \\
\hline $\begin{array}{l}\text { 3. Makes people believe that they can } \\
\text { change their environment (people has } \\
\text { common belief that they manage themselves } \\
\text { and influence an organization. "If we are sure } \\
\text { that changing the world is impossible, what is } \\
\text { training for?" E. Schein) }\end{array}$ & $\begin{array}{l}\text { 3. Lets people change only if it is necessary } \\
\text { (People in these organizations are } \\
\text { conservative, they concentrate on solving } \\
\text { problems, not on innovations) }\end{array}$ \\
\hline 4. Provides time for training & $\begin{array}{l}\text { le for employees is - "to } \\
\text { thout rest" }\end{array}$ \\
\hline $\begin{array}{l}\text { 5. Chooses the holistic approach to problems } \\
\text { (systems thinking) }\end{array}$ & $\begin{array}{l}\text { 5. Divides problems and makes employees } \\
\text { solve separate problems and subproblems } \\
\text { (analytical thinking) }\end{array}$ \\
\hline 6. Encourages open com & $\begin{array}{l}\text { 6. Limits information (only necessary work } \\
\text { and organizational information) }\end{array}$ \\
\hline 7. Is based on belief in group and team work & $\begin{array}{l}\text { 7. Is based on belief in individual work and } \\
\text { competition between employees }\end{array}$ \\
\hline $\begin{array}{cccc}\text { 8. Leaders are } & \text { available for } \\
\text { communicating (trainer) }\end{array}$ & 8. Authoritarian leaders (chief) \\
\hline
\end{tabular}

In modern companies, according to J.Boyette and J.Boyette (1), organizational culture is far from the ideal one described by E. Schein and other researchers. Unfortunately our experience proves that in many Russian companies organizational culture hinders training.

For training to take place Schein (10) suggests creating "parallel systems" in organization that would guarantee psychologically safe atmosphere for training and skill practicing and establish norms of awarding for creative thinking and experimenting. An example of such 
parallel organization is corporate universities that function in collaboration with consultants, business schools and research centers.

Informational culture and personnel training policy. Attitude to information in an organization is a component of organizational culture and is determined by its values and aims. This component is on of the definitive ones for training system. Donald A. Marshand (4) describes four types of informational culture which can be found in modern companies (table 2). Let us view this classification in details and its variants in Russian companies.

\begin{tabular}{|c|c|c|c|}
\hline $\begin{array}{c}\text { Type of } \\
\text { informational } \\
\text { culture }\end{array}$ & $\begin{array}{c}\text { Main characteristics of } \\
\text { the type }\end{array}$ & $\begin{array}{c}\text { Type of } \\
\text { personnel } \\
\text { training policy }\end{array}$ & $\begin{array}{l}\text { Main characteristics of } \\
\text { training policy }\end{array}$ \\
\hline functional & $\begin{array}{l}\text { information is used to } \\
\text { control and influence } \\
\text { employees }\end{array}$ & functional & $\begin{array}{l}\text { specialists acquire highly } \\
\text { specialized knowledge }\end{array}$ \\
\hline interaction & $\begin{array}{l}\text { atmosphere of } \\
\text { confidence, active } \\
\text { information exchange for } \\
\text { preventing problems and } \\
\text { adapting to changing } \\
\text { environment }\end{array}$ & $\begin{array}{l}\text { problem-oriented } \\
\text { training }\end{array}$ & $\begin{array}{l}\text { problem-oriented training } \\
\text { for interfunctional groups }\end{array}$ \\
\hline research & $\begin{array}{l}\text { informational activity } \\
\text { that dominates is } \\
\text { foreseeing }\end{array}$ & $\begin{array}{l}\text { perspective- } \\
\text { oriented } \\
\text { (anticipatory) } \\
\text { training }\end{array}$ & $\begin{array}{lc}\text { everyone } & \text { including top- } \\
\text { managers } & \text { is training } \\
\text { actively, } & \text { emphasis on } \\
\text { studying } & \text { external } \\
\text { experience } & \end{array}$ \\
\hline openness & $\begin{array}{l}\text { employees and managers } \\
\text { are open for new insights } \\
\text { into nature of crises and } \\
\text { for radical changes }\end{array}$ & creative training & $\begin{array}{l}\text { non-traditional forms of } \\
\text { training }\end{array}$ \\
\hline
\end{tabular}

Table 2. Classification of types of informational culture and training policy.

\section{Current needs for training.}

The most typical informational activity for functional informational culture is control. In the context of this culture functional policy of personnel training is formed. There specialists are being trained in the first place. Subject of training is concrete knowledge and skills that are necessary for specialist's work: accounting standards, norms of personnel record keeping, changes in legislation for a company's lawyer, skills of using information systems, etc. Preferred training forms are tuition, training at a work place, narrowly specialized workshops, consultations of experts. Trainers are usually tutors, experienced specialists, experts from law, audit and other consulting organizations. In the second place, system is aimed on training of departments' managers who usually are specialized in their fields and have specialized education and no management grounding. Often on the structuring stage of an organization topmanagement realizes that the management competency level of the middle managers is low. Training program includes management courses and training practice where managers learn about management functions, procedure of delegating authority and planning department work, informational instruments of management (from managing meetings to feedback procedure), etc. Thus the main principle of functional training system is - "to train every employee according to his or her duties".

In functional personnel training system the need for training for each employee is diagnosed from the point of view of organization's interests. Diagnostics of need for training of new employees includes analyses of work tasks that will be given to employees and corresponding competences (special and management skills). Assessing new employee on the stage of selection or adaptation, HR department and training manager can diagnose key 
competences by offering fragments of work tasks, and then suggest the optimal training program for a candidate. Assessment of training needs for all other employees is based on analysis of current work tasks' fulfillment, which includes evaluation of work results of the employees with the aim to find training options that could help in solving their work problems, for example, of improving low productivity.

On the one hand, in the context of this culture we can find some tendencies that are characteristic, as we said earlier, for companies that are on the stage of growth through direction (in L. Greiner model). However, in our opinion, in full measure this culture can be found in Russian companies with the strict hierarchy and the complex bureaucracy system (in large holdings and governmental organs), irrespectively of particular stage of growth.

In interaction culture specialists as well as managers trust each other enough and thus they can exchange information that is important for improving processes and growth of effectiveness. Direct information exchange about possible failures is necessary for solving problems and adaptation to changes. In information interaction culture policy of problemoriented personnel training is usually formed. Refusing to use traditional passive methods of training (lections, seminars) means forming system of problem-oriented training and conferences in which representatives of different functional departments take part. Training topics depend on problems of current importance, first of all those of interfunctional interaction of departments and employees. For example, workshop training for departments of sales and purchases in a distributor company can be devoted to development of sales strategy in the context of changes of the market demand for company's products. Such training can be led by an invited trainer, sales management expert or by distribution manager. Workshop training consists of informational and analytical parts and includes working out a program of actions. If to recall Greiner's model, our experience shows that such training policy is widely spread among Russian companies that are on the stage of growth through delegation - when interfunctional interaction is emphasized.

In research culture managers and employees try to understand future tendencies and to find the best way to ward off the possible danger. Everyone in the company - from a general director to the rank staff - should be "alert". The informational research culture, which makes the principle of foreseeing the base of the company success, do the best to orientate employees towards perspective. In this case perspective-orientated personnel training policy is formed (so called anticipatory training). In such companies first of all top-managers and main specialists who determine direction of development of an organization, are trained,. They study experience of the leading companies of different branches and regions, often invite marketing and management gurus and carry out conferences and symposiums for their employees to learn foreseeing and predicting future. Small companies that have informational research culture often send their managers and employees to study in business-training programs to the leading universities and business schools; in the first place they send them to learn new ways of thinking and to acquire new management technique. To our mind this type of culture and training policy can be seldom found in Russian companies - mostly in entrepreneur companies or in those which work in the fields of high tech and intellectual services and also in those where the key manager (usually the owner) feels "thirst for the new".

And the last type is openness culture. Such companies deliberately refuse from old business methods to become free for search of new perspectives and ideas that can contribute to changes in conditions of competition above branches and markets. A lot of companies have enclaves of openness culture where they bring information together and process it, create new products and business development scenarios, develop partner relationship with consumers and providers.

Informational openness culture creates necessary prerequisites for developing creative policy of personnel training. In this case a company is apt to create learning work groups and teams with the constant process of training. Creative training projects are supported, which destroy stereotypes of organizational behavior and let company see itself and its outer environment anew. Such organization is interested in new products of training market and often 
orders non-standard training programs, for example, creativity training for top-managers, extreme leadership training and team-creation training, finance and management account training in the form of business simulation games, cross-cultural training in mixed groups (managers and employees, employees and clients, specialists from different professional spheres, etc.) According to our research there are few such companies in Russia.

Diagnostics of need for training in an organization on the whole is usual for organizations where perspective-oriented and creative training policy dominates. Comparing strategic intentions and aims with real capacities of a company makes evident the nearest perspectives of development of an organization and gives direction in creating training programs.

Effectiveness evaluation. The way to evaluate effectiveness of training of course depends on chosen training policy and informational culture. Functional policy of personnel training is aimed on such results as quantity growth in fulfilling a certain function. Sales training is expected to cause sales growth. Management training programs are expected to cause profit growth.

In case of problem-oriented training policy in a company the criterion of effectiveness evaluation of the training program is evident - that is solving a certain problem or creating a method of solving problems of a certain type. Sales training is intended to teach sellers to make a decision (to follow a standard), for example, in a situation of communication with a conflict client, and to stimulate a company to work out a corresponding standard of behavior and order of interaction between departments in a situation of that kind in the future. Management training program will be created to solve a certain management problem.

A company which is perspective-oriented in personnel training will estimate effectiveness of its training programs by the fact of creating information pool after every training practice and training course and by the fact of possibility of being well informed about the latest tendencies of development of the market, branch, business, region. Sales training is effective if due to it our sellers learn about the new sales technologies. In management training courses company's managers learn about new management methods, for example, of balanced scorecard or of the theory of talent management in a company.

Training result in a company where creative policy of personnel training dominates is often unpredictable. In Russian companies this result is equated with appearance of a new project or creating new business branch in a company. However, absence of immediate result of training is also considered to be a result there. The very fact of thinking and communicating on important topics is considered valuable.

Thus we saw what influence informational culture has on creating of personnel training policy and what types of culture and policy are mostly spread in Russian companies.

\section{Analyzing training and development experience of Russian policies.}

The experience of School of Management of St. Petersburg University in organizing corporate training programs shows that nowadays Russian companies can be divided into tree groups by degree of development of personnel training system and by role it plays in strategy of company's development.

The 1 group. Companies which do not consider training as independent and significant activity. There is no deliberate training policy and structure in a company and no evident prerequisites for developing system of personnel training. Employees can enter educational institutions if they like to or attend training practice in educational or consulting companies. Results of this training can be estimated only on individual level: "What has this training given to me?" Training in an institute of higher education or attending seminars often stimulates an employee to leave his or her company because communication in educational environment and involvement in professional net causes circulation of information about internal environment of different organizations, stimulates comparison and contributes to successful career. From time to time spontaneous training programs appear and they are mostly caused by accidental factors. Spontaneous contacts of a company with training organizations without preliminary diagnostics 
of training needs and without realized training aims lead either to dissatisfaction of both employees, who are forced to train, and managers, who pay for odd and undesired product, or to momentary emotional satisfaction and interest in training (mostly due to competence and personality of a trainer) without long-lasting results and their use in everyday company's activity.

Example 1. There is a company with 25 employees which has worked for 3 years in the field of purchase and sale of industrial building materials. It has several permanent clients and is being managed by a proprietor. Suddenly it reduces sales. The manager makes a request in a consulting training company to analyze the current situation and to train employees. The company has a primary (undeveloped) information interaction culture. After that the employees are trained according to the anti-crises training program and the sales training program for field agents. During the anti-crises training new work program is developed and it is put into practice successfully. The manager is satisfied with the results, but still he decides to stop collaborating with the training organization because he thinks that the aim is achieved and the problem is eliminated. In one year and a half the situation repeats, but the company can not use the methods to solve this problem itself because acquired knowledge was not conserved by appropriate practice of everyday work and thus it did not turn into experience and skills of sales management and anti-crises activity. Thus the manager has to turn for help to the training organization again.

Example 2. A wholesale buyer exists for 7 years in food industry and has 600 employees. As a new general director hired by proprietors comes, sales training begins and it has as its object: to introduce the general director to the group and to develop the common approach to the sales management. The company has strict hierarchy and functional information culture. A hired trainer organizes intense interaction between the employees, which is typical for the other kind of information culture and causes criticism of the situation in the company, dissatisfaction with the proprietors' management style and conflict between the new general director and the most active elements of the group. Post-training life of the company is characterized with long-lasting confrontation in the group and low effectiveness of the business. During the following two years those employees who had been trained in business programs conceal this fact from the management because of its negative attitude to training.

The 2 group. Companies where personnel training is one of the functions of personnel manager. Training function is a part of personnel department. Training policy and personnel development policy are being developed. This is a duty of a personnel manager or a director for human resources. His or her function is to organize training and to hire trainers from outside a company. This policy can be called testing policy. A company tests different forms and methods of training, different trainers and partnership with different training organizations thus learning about different concepts and methodologies of personnel training process.

Example 1. A net of restaurants and cafes exist for 7 years on the Russian market. It has the central office in St. Petersburg and several regional sub-units in Russian cities. There are 1250 members of the staff. The company has mixed type of information culture - functional information research culture. Functional information culture is more typical for service departments, and research culture - for top-management.

During the last 2 years the personnel department by itself created the system of constant training for service personnel. Now the need of training for the middle management became important to acquire management skills and for the top-management to learn strategy management. The personnel department organized tender to carry out training in management skills and in this tender 5 training companies from St. Petersburg, 3 training companies from Moscow and two institutions took part. The company chose St. Petersburg company to put into practice its training program and ordered the strategy management training practice in one of the colleges. Studies were successful but later the problem of difference in terminology and management theory arose as the result of different training methods. Later the company ordered an additional training practice to form common management outlook and common management vocabulary for its managers. According to employees of the personnel department the most 
difficult in organizing of training process was the problem of choice of methodology in accordance with company's strategy of personnel development, which in the upshot they asked the institution specialists to solve.

The 3 group. Companies where training is a strategic problem of management. A certain level of training need in a company is reached. There is a functional guarantee of this process - inner, outer or mixed. The main principles and values of training are formulated and declared. Top-management is involved in organizing and carrying out training in companies of this group. Managers lead several corporate training practices. Top-managers themselves learn both inside a company and outside it, bringing results of their individual training back in their organization.

Example 1. A publishing polygraphic company exists for 9 years on the market and is one of the leading organizations in its market niche. 150 employees work in production, sale and support departments of the company. The company has information interaction culture with enclaves of openness culture.

For the last 4 years the company regularly ordered different trainings for the personnel. Top-managers of the company are studying in the MBA program. Having attended course of human resources management in an organization, top-managers created the new position - a training manager - and charged the new employee with forming a training concept. The training manager formulates a personnel training concept in collaboration with one of the leading business-schools in Russia. The main principles of personnel training in the company are formulated and declared. Entry training is obligatory for all the new employees. A program of tuition in sales training is being constantly used. Training of developing type becomes the bonus for an employee and a part of a compensation package.

In our opinion, belonging of a company to any one of groups described before depends on the number of facts - information culture which was formed in a company, a stage of growth of an organization, certain characteristics of the business environment, a type of branch and current situation on the labor-market in a region.

\section{Important problems of the market of corporate training.}

In conclusion we would like to note several important problems which hinder effective development of the market of corporate training.

We have to accept that one of the sources of problems of training effectiveness is companies themselves. Mainly it is because companies have difficulties with setting aims of training and with describing problems which they want to solve as the result of training. Partly this problem is the outcome of status of a personnel manager in Russian companies and it arises in companies where a personnel specialist fulfils functions of a coordinator-administrator only and does not influence much policy of personnel management. In such cases personnel manager does not really realize why top-managers initiate this or that training program, which he must organize. As a result, personnel manager can be ineffective "link" in organizing this process both in the situation when this training is realized by inner strength of a company or when it is realized by its outer strength.

On the other hand, the problem of equal importance is that of dissatisfaction with training results, which is caused by the great variety of training service provider. On the whole it can be defined as "the lack of client orientation" of many Russian trainers or as a lack of qualified specialists who are ready to work with concrete problems of concrete companies-clients. On the one hand, it is because of the lack of experience in training in many fields. However, as our practice shows, if a trainer had been educated abroad and worked there it does not solve the problem, unfortunately, because the domestic audience has its special traits and foreign methods do not always seem adequate for it.

Thus, in this article we tried to mark out and analyze the main tendencies in personnel training and development in modern Russian companies. We also saw that training policies in 
Russian companies are formed under the influence of the complex of factors such as specific characteristics of the national environment, a stage of life-cycle, information culture of a company and role of personnel training in strategy of company's development

\section{Literature}

1. Boyette J., Boyette J., 2002. Guide through the wisdom kingdom: best ideas of management gurus. M., 2002.

2. Ivanova E. Personnel training: no alternative. Personnel elite, 34 (268), 2002.

3. Kapustin S.N., Krasnova N.L. Marketing approach to corporate training. Marketing in Russia and abroad, 4, 2000.

4. Marshand D.A. The art of management. 1999.

5. Fey C.F, Pavlovskaya A.G., Tang N. Are human resources management practices are universal? Comparison of Russian, Chinese and Finnish practices. Russian Journal of Management. - \#1, 2004.

6. Argyris C., Schon D. Organizational Learning. Reading, Mass.: Addison-Wesley, 1996.

7. Greiner, L. Evolution and revolution as organizations grow/ L. Greiner// Harvard Business Review. - 1972, July-August. - P.37 - 46. (translated by: Klemina T.N. Evolution and revolution as organizations grow/ T.N. Klemina, L.E. Greiner // St. Petersburg State University bulletin. Management.- 2002. - \#.4-P .76-94).

8. Kay, J.A. Foundations of Corporate Success: How business strategies add value. Oxford: Oxford University Press, 1993.

9. Kim D.H. The link between Individual and Organizational Learning// Sloan Management Review, 1993, Fall, p.37-50.

10. Mumford A. Making experience pay - McGraw Hill, 1980.

11. Schein E.H. Organizational and Managerial Culture as a Facilitator or Inhibitor of Organizational Learning. Working Paper for the MIT Organizational Learning Network, 1994, May 19.

12. Senge P. Leading Learning Organization // Training and Development1996, December, p.3638 . 